\title{
Limnological Study of Piraquara River (Upper Iguaçu Basin): Spatiotemporal Variation of Physical and Chemical Variables and Watershed Zoning
}

\author{
Paulo Henrique C. Marques ${ }^{1 *}$, Haydée Torres de Oliveira ${ }^{1}$ and Eunice da Costa Machado ${ }^{2}$ \\ ${ }^{I}$ Departamento de Hidrobiologia; Universidade Federal de São Carlos; Via Washington Luiz Km 235; C. P. 676; \\ 13565-905; São Carlos - SP-Brazil. ${ }^{2}$ Centro de Estudos do Mar; Universidade Federal do Paraná; Av. Beira Mar, \\ $s / n ; 83255-000 ;$ Pontal do Paraná - PR - Brazil
}

\begin{abstract}
The Piraquara river basin (Upper Iguaçu River basin - Brazil) was studied as an ecological system throughout a complete seasonal cycle, comprising the rainy and dry season. Analyzes of 16 physical and chemical water variables (dissolved oxygen, biochemical oxygen demand, temperature, $\mathrm{pH}$, conductivity, total nitrogen, total phosphorus, ortophosphates, nitrite, nitrate, ammonium, reagent silicate, total suspended solids, chlorophyll - a, flow velocity and depth) showed correlations between water composition and watershed physiographic features, and the Principal Component Analysis allowed to evidence spatial gradients and seasonal differences. The sampling points were clustered in patches with homogeneous behavior, according to ecologycal concepts: patch 1, with strong influence of Serra do Mar mountains; patch 2, medium course, under Piraquara Dam influence and patch 3, under wetlands influence. Two main factors of serial discontinuity were identified: the Piraquara dam effect and the influence of wetlands. The watershed zoning based on limnological characteristics seeks to subsidize research and biomonitoring for this public springs area.
\end{abstract}

Key Words: Lotic Ecossystems, Water Chemistry, Subtropical Stream, River Continuum, Upper Iguaçu Watershed

\section{INTRODUCTION}

Watersheds are considered natural units for environmental management under ecological, social and economic points of view. A lot of attention has been given to water quality, a fundamental natural resource for the sustainability of the system. Human activities in a catchment area result changes in the physical, chemical and biological features of the drainage waters, frequently damaging to the well-being of the people who use them. This fact, together with perspectives of world shortage of aquatic resources in the near future, has motivated research on land use and water quality in several countries (Townsend et al., 1997; Carvalho, 1996; Mulholland, 1992).

The integrated study of watersheds resulted in the development of ecological theories for lotic ecosystems. Among them, the river continuum concept (Vannote et al., 1980; Minshall et al., 1985; Baptista et al., 1998) is highlighted as a conceptual model which proposes the existence of a previsible continuum of biotic and abiotic phenomena from source to mouth. Biological processes downstream are closely related to particulate organic matter (POM) from upstream.

\footnotetext{
* Author for correspondence
} 
The theory was complemented by the patch dynamics concept (Pringle et al., 1988; Bretschko, 1995), which considered both the hydraulic regime and the catchment landscape heterogeneity, interpreting the lotic ecosystem as a mosaic of patches with particular characteristics, but with strong interactions among the adjacent patches. These patches were delimited by serial discontinuity factors (Ward, 1994, Sabater et.al., 1989) which could be either of physiographyc origin or from anthropogenic activity. These factors of discontinuity, acting over a certain point of the river, determine a new ecosystem behavior in the next patch, and can be measured by the distance in which their influence are identified downstream.

The definition of river sections whose biotic and abiotic features form homogeneous units enables the evaluation of the trophic state, biotic composition and the possible interactions between catchment land use and aquatic system integrity. An efficient watershed planning or management program should be based on the identification of the sub-basins environmental gradients, resulting in spatial ordering in accordance with their limnological characteristics (Rios and Calijuri, 1995; Camargo et al., 1996; Branco and Necchi Jr., 1997).

This work intended to study the spatiotemporal patterns of the river water, with the specific objectives:

- to describe the spatial gradient of limnological variables of the river basin taken as ecological system;

- to identify and characterize river sections presenting homogeneous behavior, and propose a watershed zoning based on limnological variables;

- to identify the main serial discontinuity factors and their downstream influences.

The study was based on the fact that the Upper Iguaçu river basin accounted for $84 \%$ of the water supplied to the metropolitan region of Curitiba (capital of Paraná state, Brazil) and, at present, constitute one of the main environmental problem. Piraquara river was chosen as representative of the whole basin due to the following characteristics:

- the river flow is roughly similar to an east-west transect (Fig.1b), crossing a landscape gradient which starts in a highly preserved environment and reaches the outskirts of the metropolis;
- the main types of soils (Maack, 1981) and the four main vegetable formations (Klein et al, 1962; Ziller, 1993) of the Upper Iguaçu Basin are represented in its $22 \mathrm{~km}$ of extension;

- the Piraquara river suffers the smallest level of anthropogenic interference in the region. The native vegetation is the main determinant component of its landscape variability, according to Rizzi and Guiera (1996).

\section{MATERIALS AND METHODS}

Study area: The Piraquara river basin (area: 9.790 hectares; geographical coordinates: $25^{\circ} 27^{\prime} 30^{\prime \prime}$, $25^{\circ} 32^{\prime} 30^{\prime \prime} \mathrm{S}$; 48 59'00", 4907'30" W; altitude: 1350 to $970 \mathrm{~m}$ above sea level), embraces approximately $43,5 \%$ of the Piraquara District (metropolitan area of Curitiba - Pr). The source is located in the west slope of "Serra do Mar" Mountains, and the basin comprises the "Mananciais da Serra" State Park, an indigenous landscape preserved since 1912 (Vicentini et al., 1993) inside the ombrofilous dense forest domain (Veloso et al, 1991). This region is designated as special area for the provision of water supply.

Climate and Hydric Regime: The climate is described by Köppen classification system as $\mathrm{Cfb}$ (subtropical humid mesothermic), with fresh summers and frequent occurrence of severe winter frosts, and no dry season. The relative air humidity varies between 79 and 86\% (Vicentini et al, 1993).

Land Use: The Piraquara river basin comprises a few urban agglomerations and absence of industrial activity. The agricultural activity is underdeveloped due to the low fertility of the soils. Most of the Piraquara City effluents are drained by the Iraizinho river basin, and the effluents of the City of São José dos Pinhais are drained by the Itaqui river, thus giving to Piraquara Basin a privileged sanitation condition. Table 1 shows the characteristics of the watershed land use. Fig.1(b) shows the Upper Iguaçu basin, the Piraquara River sub-basin delimitation and the representation of two important landscapes (urban patches and ombrofilous dense forest patches). Fig.1(c) shows the watershed, presenting the sampling points location and the landscape units adopted in this study. More detailed description is shown in Table 2. 
Table 1 - Land use in Piraquara River basin.*

\begin{tabular}{lcc}
\multicolumn{1}{c}{ Land use } & Area (ha) & \% of basin \\
\hline I - Atlantic rainforest & 3095 & 31,61 \\
II - Second, third and fourth phasis of forest sucession (remnants) & 3292 & 33,63 \\
III - reforestation by Eucaliptus sp. & 157 & 1,60 \\
IV - Oedaphic Fields (converted to pasture) & 2418 & 24,70 \\
V - Atlantic alluvial forest (include wetlands and riparian forest) & 519 & 5,30 \\
VI - Agriculture & 170 & 1,74 \\
VII - Urban areas & 139 & 1,42 \\
\hline
\end{tabular}

* Adapted from Rizzi and Guiera, 1996.

a)

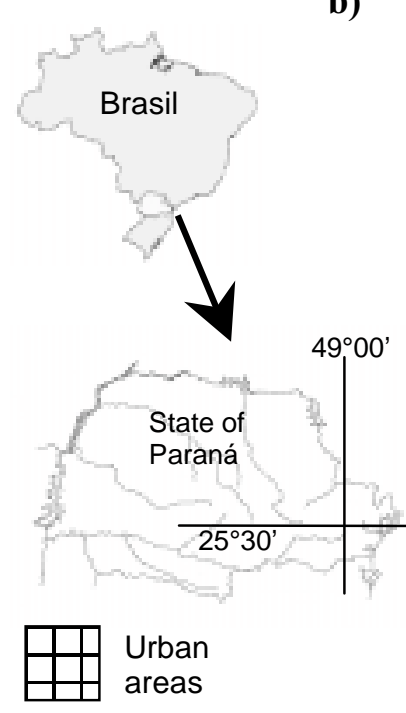

BY Serra do Mar

WETLAND

Meandering pattern

Oxbow lakes

Hydromorphic soils

FIELDS

Araucaria remnants

Red-Yellow allitic Latosol

ATLANTIC RAINFOREST

Ombrofilous Dense Forest

Pre-cambrian formation

Litholic soils; Cambisol

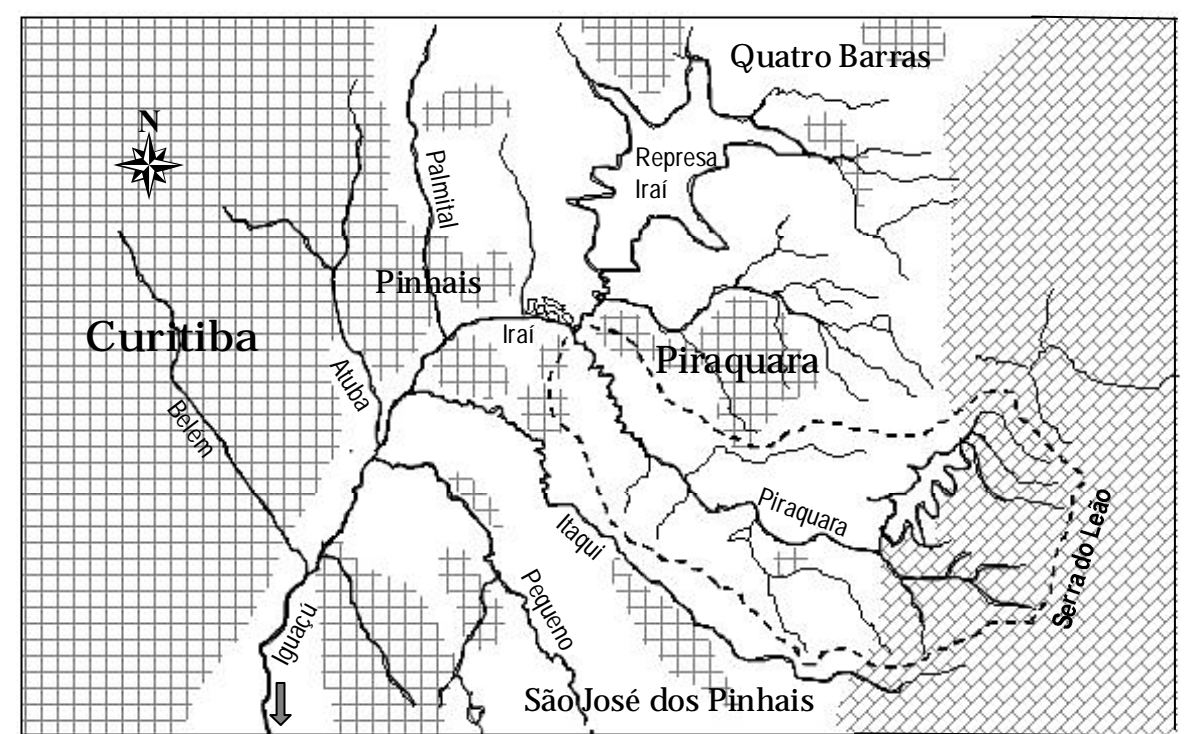

c)

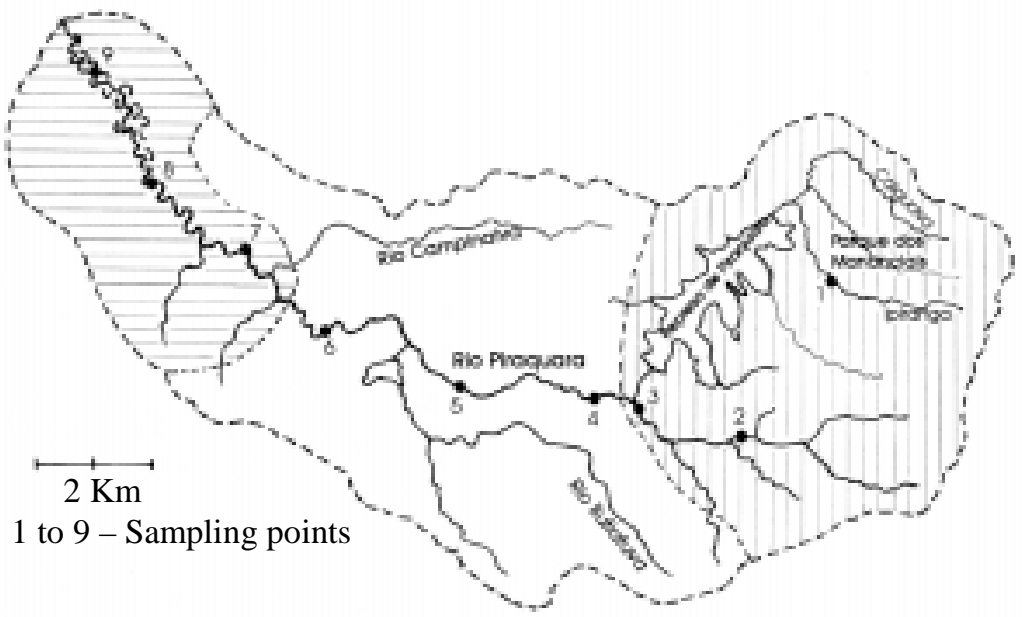

Figure 1 - a) Location of the study area; b) Upper Iguaçú Basin: Hidrography, delimitation of Piraquara river basin, urban and forest areas (scale $=1: 250.000)$; c) Piraquara river basin, showing the sampling points and the main landscape units. Based on COMEC, 1980 and aerial image 1996. 
Table 2 - Physiografic features in the sections of basin which are represented by each sampling point.*

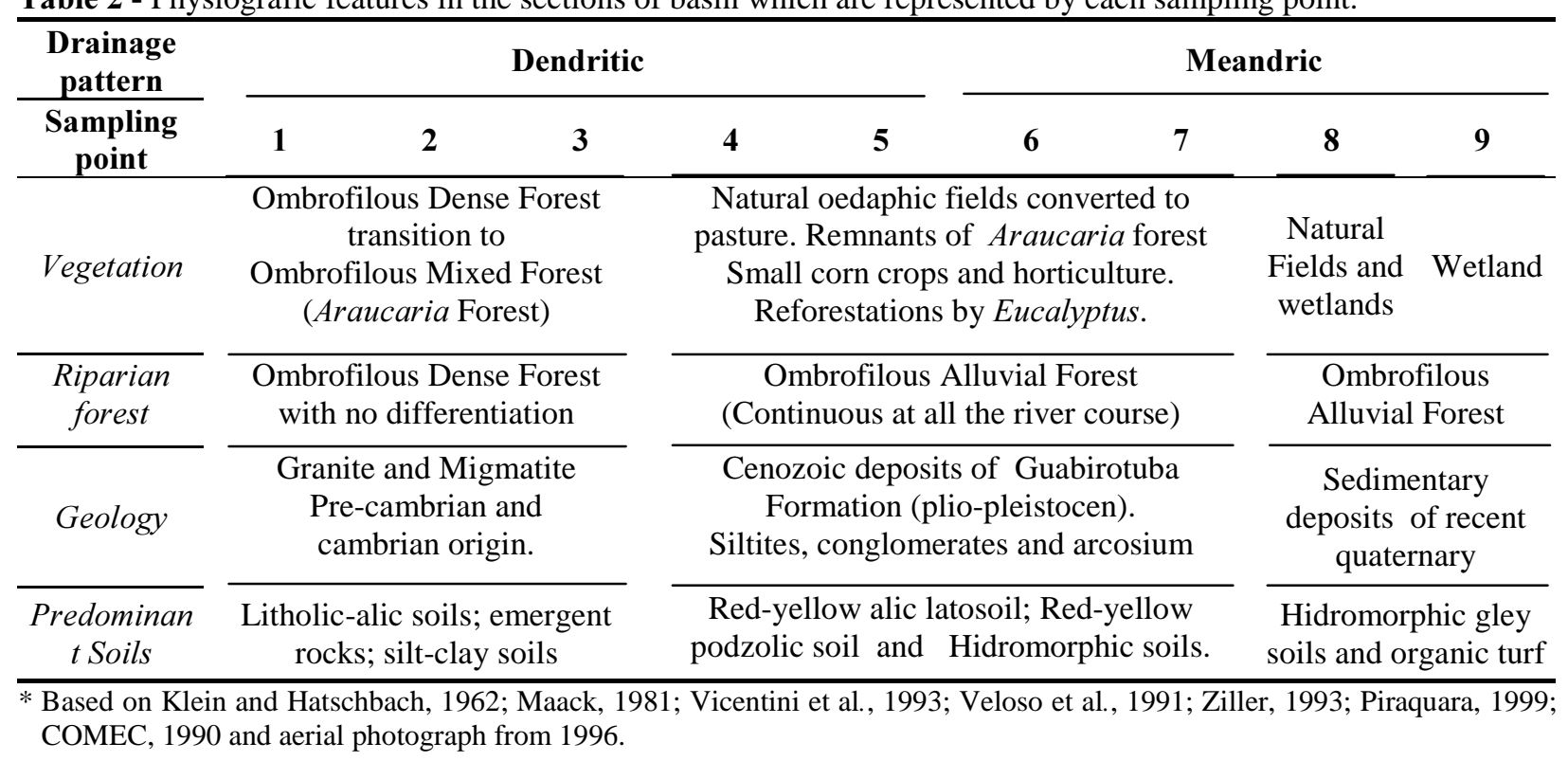

Sampling: Nine sampling points were distributed along the main course of the river, in agreement with the landscape units. Six field campaigns were carried out in the span of one year (Nov 1998; Jan, Mar, Jun, Aug and Sep 1999). Water samples were collected according to method described in CETESB (1987), with sampling repetition after 15 minutes of the first water collection.

The variables and respective analytical methods were: flow velocity $(\mathrm{m} / \mathrm{s})$ and depth $(\mathrm{m})$ according to CETESB (1988); water temperature $\left({ }^{\circ} \mathrm{C}\right)$ and $\mathrm{pH}$ with potentiometer INGOLD-206; dissolved oxygen $\left(\mathrm{mg} . \mathrm{L}^{-1}\right)$, biochemical oxygen demand $\left(\mathrm{mg} . \mathrm{L}^{-1}\right) ; \quad$ conductivity $\left(\mu \mathrm{Scm}^{-1}\right), \quad$ dissolved inorganic phosphate $\left(\mu \mathrm{g} . \mathrm{L}^{-1}\right)$, nitrate $\left(\mu \mathrm{g} . \mathrm{L}^{-1}\right)$, nitrite $\left(\mu \mathrm{g} . \mathrm{L}^{-1}\right)$, ammonium $\left(\mu \mathrm{g} . \mathrm{L}^{-1}\right)$, ortosilicate $\left(\mu \mathrm{g} . \mathrm{L}^{-1}\right)$, total nitrogen $\left(\mu \mathrm{g} . \mathrm{L}^{-1}\right)$ and total phosphorus $\left(\mu \mathrm{g} . \mathrm{L}^{-1}\right)$ according to Koroleff (1976); total solids in suspension $\left(\mathrm{mg} . \mathrm{L}^{-1}\right)$ and chlorophyll-a $\left(\mu \mathrm{g} . \mathrm{L}^{-1}\right)$ by spectrofluorescency according to Strickland and Parsons (1972).

\section{RESULTS AND DISCUSSION}

Fig. 2 shows water temperature, air temperature and total rainfall as compared to the average precipitation in the period 1900-1990 and presents a typical regional climatic pattern divided in two different seasons: the warm and rainy summer (samples from November 98 to March 99) and the cold and dry winter (June to September 99). Water temperature and accumulated precipitation in 5, 15 and 30 days before each field campaign denote the major differences of these seasons.

To analyse the limnologic patterns both longitudinally and temporally, the results were graphically plotted (Figs. 3, 4 and 5). Each variable was represented in relation to the sampling points 1 to 9 (Fig.1c). The temporal variation was represented by three data sequences:

- rainy season: average of samples taken in November, January and March;

$\triangle$ dry season: average of samples taken in June, August and September;

- annual: mean and standard deviation of all samples. The standard deviation comprised the averages and deviations of both the dry and rainy seasons.

The results showed that the dissolved oxygen (DO) concentration was directly related to flow velocity and inversely related to water temperature, depth and total suspended solids (TSS). The highest values were observed in the months when temperature and TSS were lower, because these variables can interfere in the OD saturation degree, as well as in the points with higher turbulence (1 to 3 ). The lower OD values at point 9 were due to flow velocity and high contents of organic matter evidenced by the DBO5 higher values, a typical characteristic of wetland environments. 
a) Water Temperature

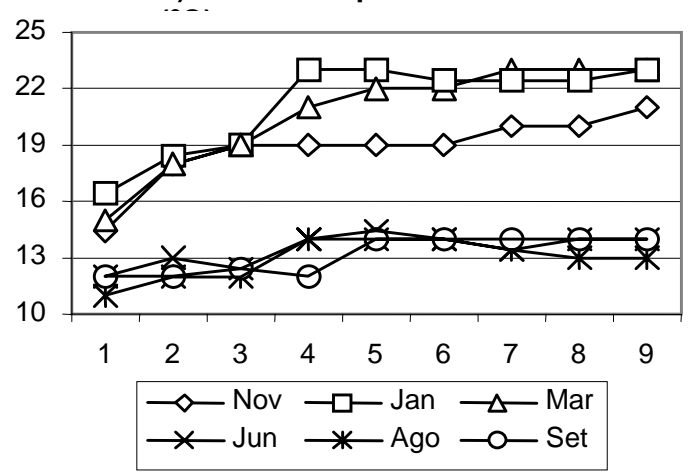

c) Accumulated

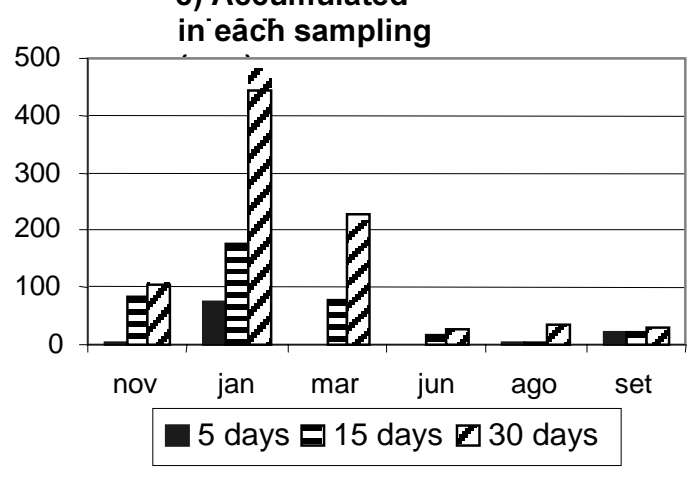

b) Air Temperature - monthly average $\left({ }^{\circ} \mathrm{C}\right)$

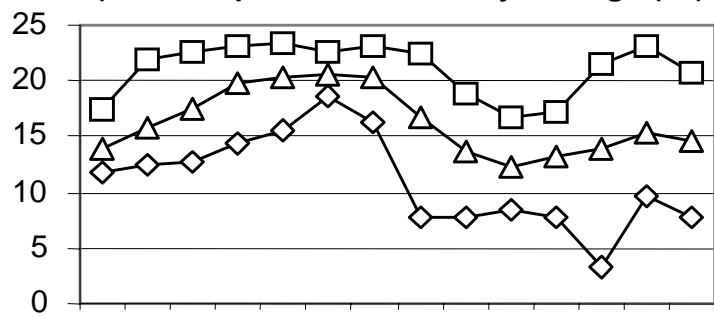

$\smile$ Min $\square-\operatorname{Max} \neg-$ Med

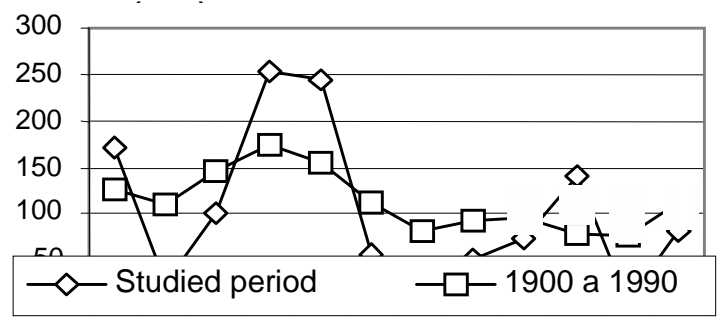

Figure 2 - a) Water temperature by sampling point; b) Air Temperature (monthly average); c) Accumulated rainfall in 5, 15 and 30 days before each sampling; d)Rainfall (monthly average).

* Source of graphs b, c and d: SIMEPAR - Sistema Meteorológico do Estado do Paraná.

In this point, must of the results present very similar patterns to those of lentic ecossystems.

$\mathrm{pH}$ values seemed to indicate a buffering condition, and the values observed in sections 1 to 3 could be related to humic and fulvic acids (yellow substances) originated by forest littering, and in point 9 to $\mathrm{CO}_{2}$ released by the decomposition of organic matter.

The values of total suspended solids (TSS) were higher in the rainy period, and presented increasing gradient according to the catchment area. Particularly outstanding was the influence of the Piraquara Dam (point 4) and the wetlands (point 9), where the removal of particles by sedimentation could be clearly observed. The same behavior was observed with regard to silicate $\left(\mathrm{Si}(\mathrm{OH})_{4}\right)$ and, at point 9, the lowest values could also be related to the $\mathrm{pH}$, which interfered in the silicate solubilization strength. The low conductivity values reflected little interference due to pollution (fertilizers or domestic residues). 
a)

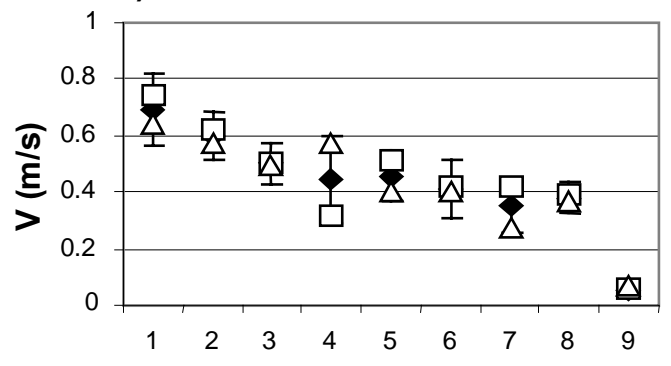

c)

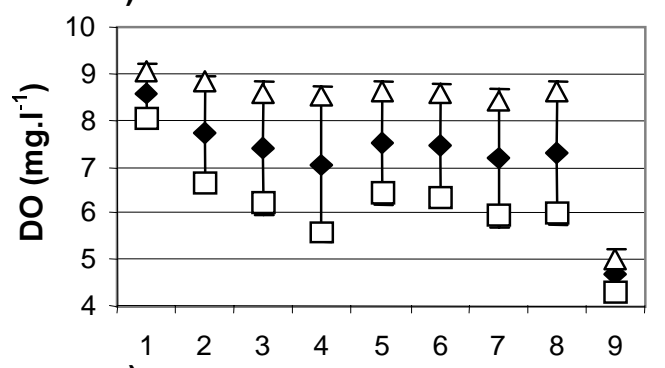

e)

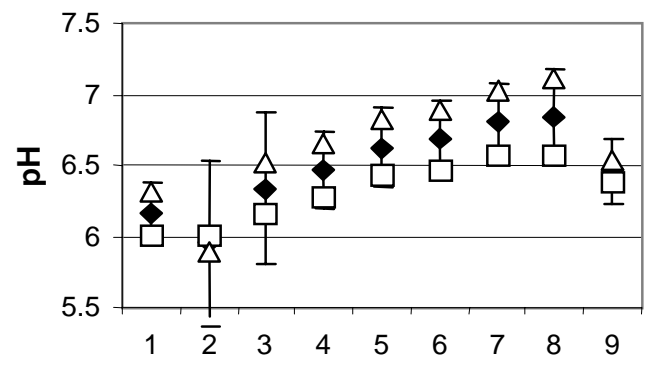

g)

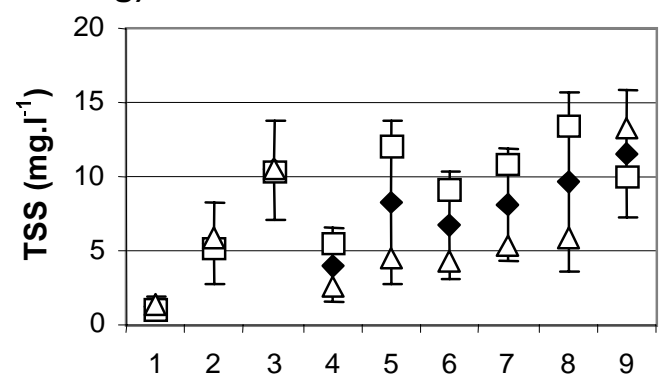

b)

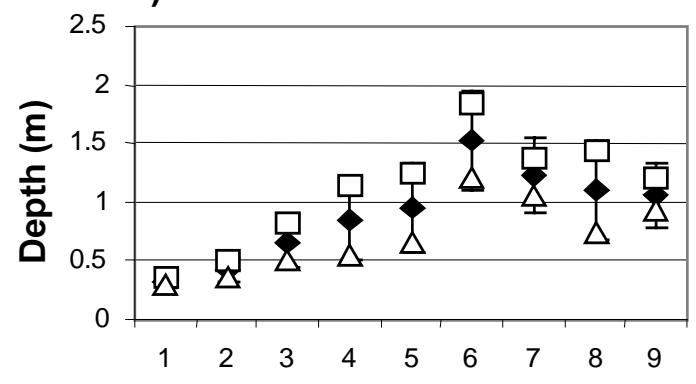

d)
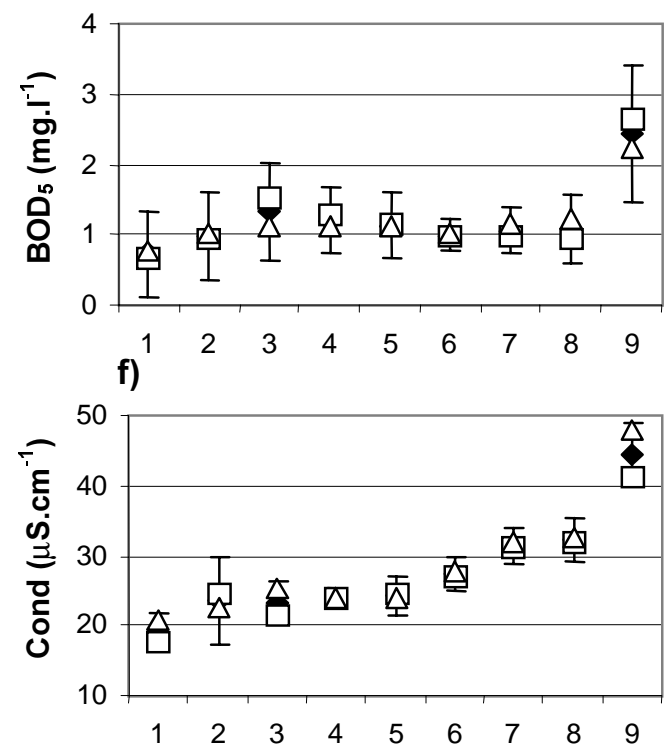

h)

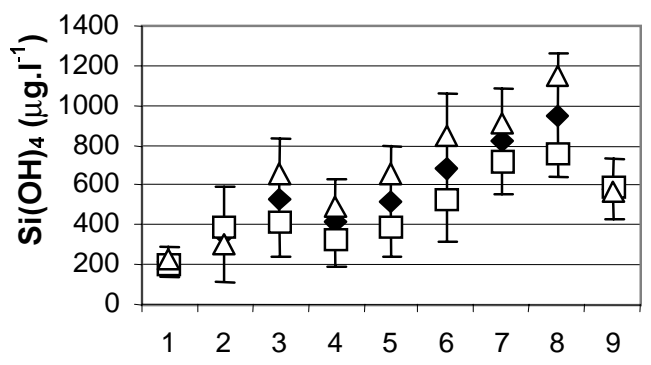

Figure 3 - a) Flow velocity (V); b) Depht; c)Dissolved Oxigen (DO); d)Biochemical Oxigen Demands $\left(\mathrm{BDO}_{5}\right)$; e)pH; f)Conductivity; g)Total Suspended Solids (TSS); h)Reagent Silicate ( $\left.\mathrm{Si}(\mathrm{OH})_{4}\right)$. Symbols:

$\square$ Rainy Season average; $\triangle$ Dry Season average; $\bullet$ Annual average and standard deviation. Values refer to sampling points 1 to 9 . 
a)

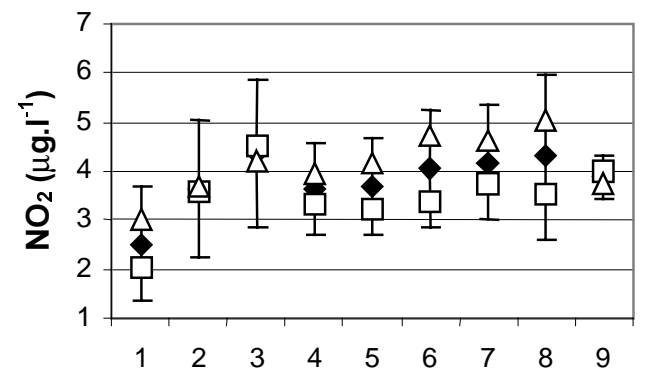

c)

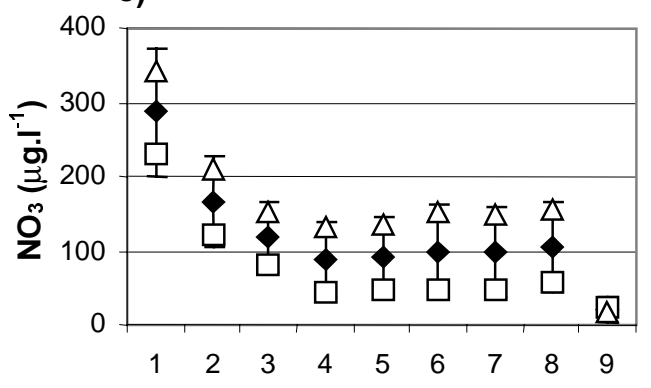

e)

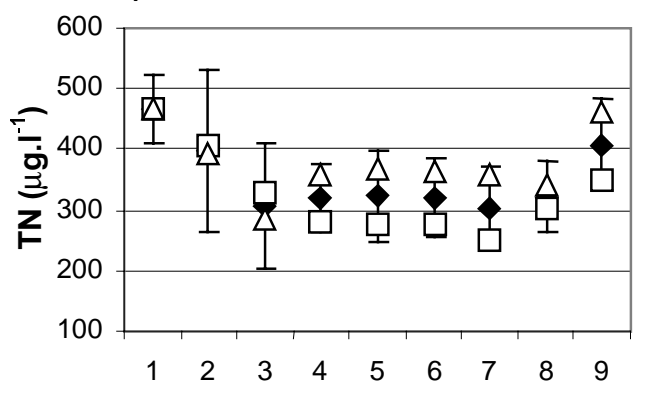

b)

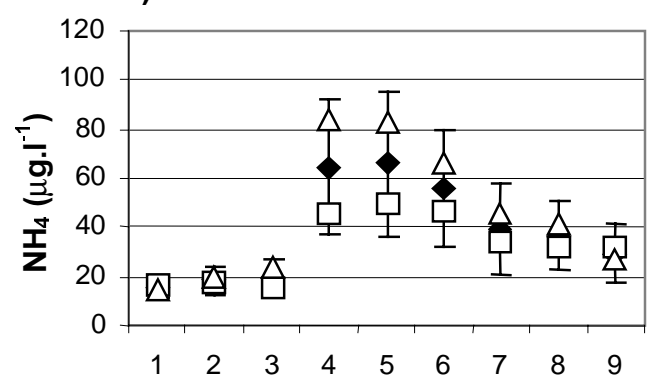

d)
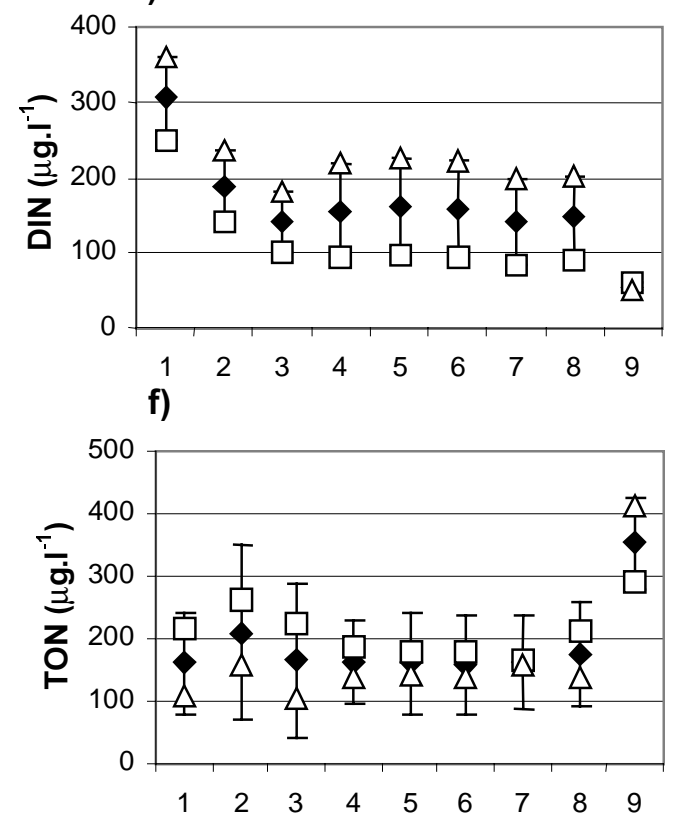

Figure 4 - a) Nitrite $\left(\mathrm{NO}_{2}\right)$; b) Ammonium $\left(\mathrm{NH}_{4}\right)$; c) Nitrate $\left(\mathrm{NO}_{3}\right)$; d) Dissolved Inorganic Nitrogen (DIN); e) Total Nitrogen (TN) and f) Total Organic Nitrogen (TON) Symbols: $\square$ Rainy Season average; $\triangle$ Dry Season average;

Annual average and standard deviation. Values refer to sampling points (1 to 9).

Higher concentrations of inorganic nitrogen occurred in the dry period, an opposite behavior if compared to the organic forms. Cconcentrations of nitrite ion $\left(\mathrm{NO}_{2}\right)$ were close to the detection limit of the method employed, with no outstanding variations which would denote pollution sources. As for the ammonium ion $\left(\mathrm{NH}_{4}\right)$, a concentration peak was registered starting at point 4, which slowly decreased downstream, indicating clear influence of decomposition processes in the Piraquara Dam. The higher values of total nitrogen (TN) observed at points 1 to 3 were due to the forest littering processes developed in the Serra do Mar mountain slope, which acts as an orographic barrier for the oceanic air masses loaded with humidity and nutrients. In this section, the largest fraction of nitrogen was in inorganic form, mainly the nitrate ion $\left(\mathrm{NO}_{3}\right)$, probably due to the availability of dissolved oxygen. Conversely, the high concentration of total nitrogen verified at point 9 was related to organic fraction, because of the assimilation by plants and microorganisms, which constituted the autochthonous organic matter in the wetland environment. These results showed the tendency of the organisms to assimilate nutrients in the inorganic form in the downstream sections, according to the river continuum concept (Vannote et al., 1980; Minshall et al., 1985), and it could be interpreted as the nutrient retention capacity foreseen by the nutrient spiraling concept (Newbold, 1982; Mulholland, 1992; Maltchick et al., 1994). 
a)

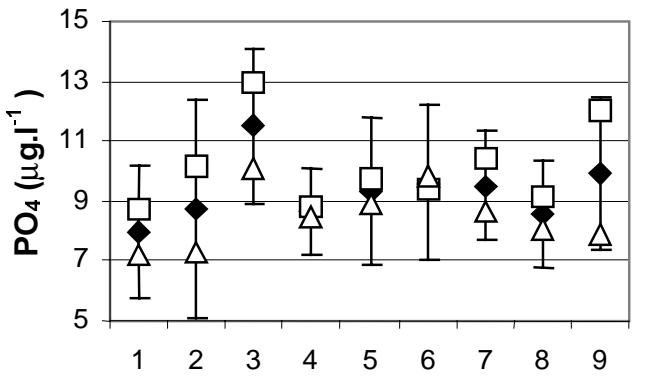

c)

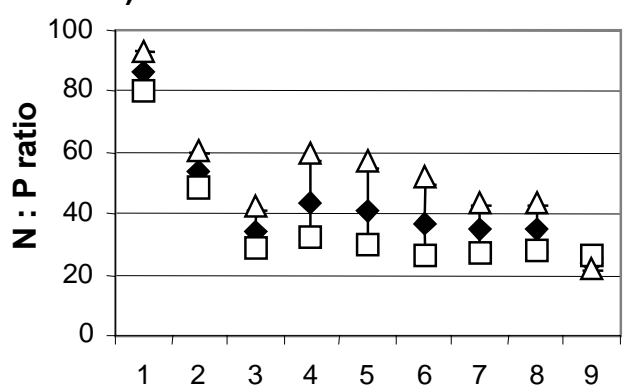

b)

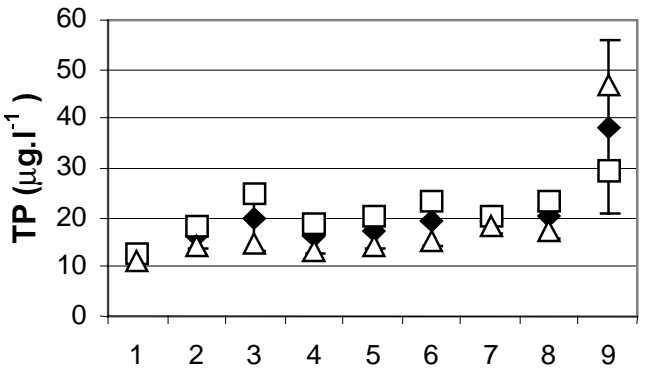

d)

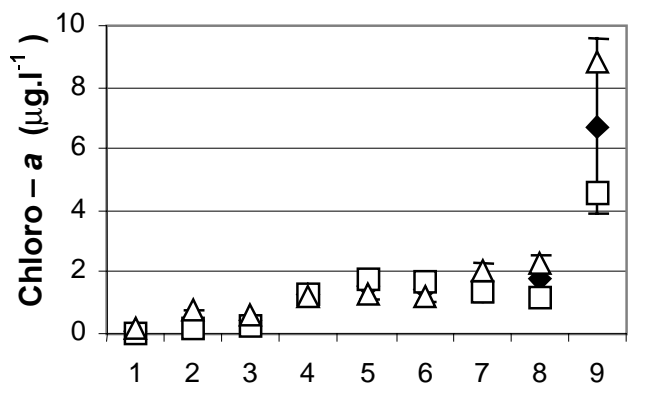

Figure 5 - a)Phosphate $\left(\mathrm{PO}_{4}\right)$; b)Total Phosphorus (TP); c)Nitrogen/Phosphorus ratio (N:P) and d)Chlorophill-a (Chloro- $a$ ). Symbols: $\square$ Rainy Season average; $\triangle$ Dry Season average; Annual average and standard deviation. Values refer to the sampling points (1 to 9).

The geological features of the basin produce small phosphorus export, transported mainly in its particulate organic fraction, which characterizes it as a main growth limiting factor, as shown by the NT/PT ratio. In the rainy period, higher phosphorus values were observed, as well as a tendency for a slight reduction in its concentration at point 4 , due to effluents of the dam.

Next to null values of chlorophyllian pigments (chlorophyll- $a$ ) was observed at points 1 to 3 , and increasing values from point 4 due to the dragging of chlorophyllian cells from the dam, without seasonal distinction. The peak of chlorophyll observed at point 9, more accentuated during the dry season, indicated production processes of planctonic and periphitic biomass in the wetlands. At this point we also verified that the NT/PT ratio approached the range of 10-20, considered as ideal $\mathrm{N}$ and $\mathrm{P}$ supply rate for the algae (Reynolds, 1984).

Watershed zoning: In order to establish a river zoning based on the limnological gradients observed, we used the Principal Component Analysis (Asensio, 1988). As the characteristics of sampling point 9 (wetlands) were quite different from the observed gradients in other sampling points, its values could produce a polarization of the cloud of points in the PCA analysis, damaging the evidence of the patterns which we wanted to demonstrate. At first, it was adopted the exclusion of point 9 from the gradient analysis (Fig 6), which was executed starting with a matrix of 16 variables corresponding to the sampling points 1 to 8 , in six sampling times (months), in a total of 48 cases. Each point plotted on the graph represented the average of sample responses, identified by the month's initials and the number of the sampling point. (e.g.: Se3 = sampling of point 3, in September).

Fig. 6 showed that there was a group of points around point 1 (corresponding to the source of the river). A tendency for the formation of a gradient could be observed starting at points "2" towards points " 8 ". The samples collected in the rainy period were located in the inferior quadrants, whereas the samples for the dry period were in the superior quadrants. The lines drawn on this graph showed this temporal distinction, which was more evident from the points " 3 " onwards. 


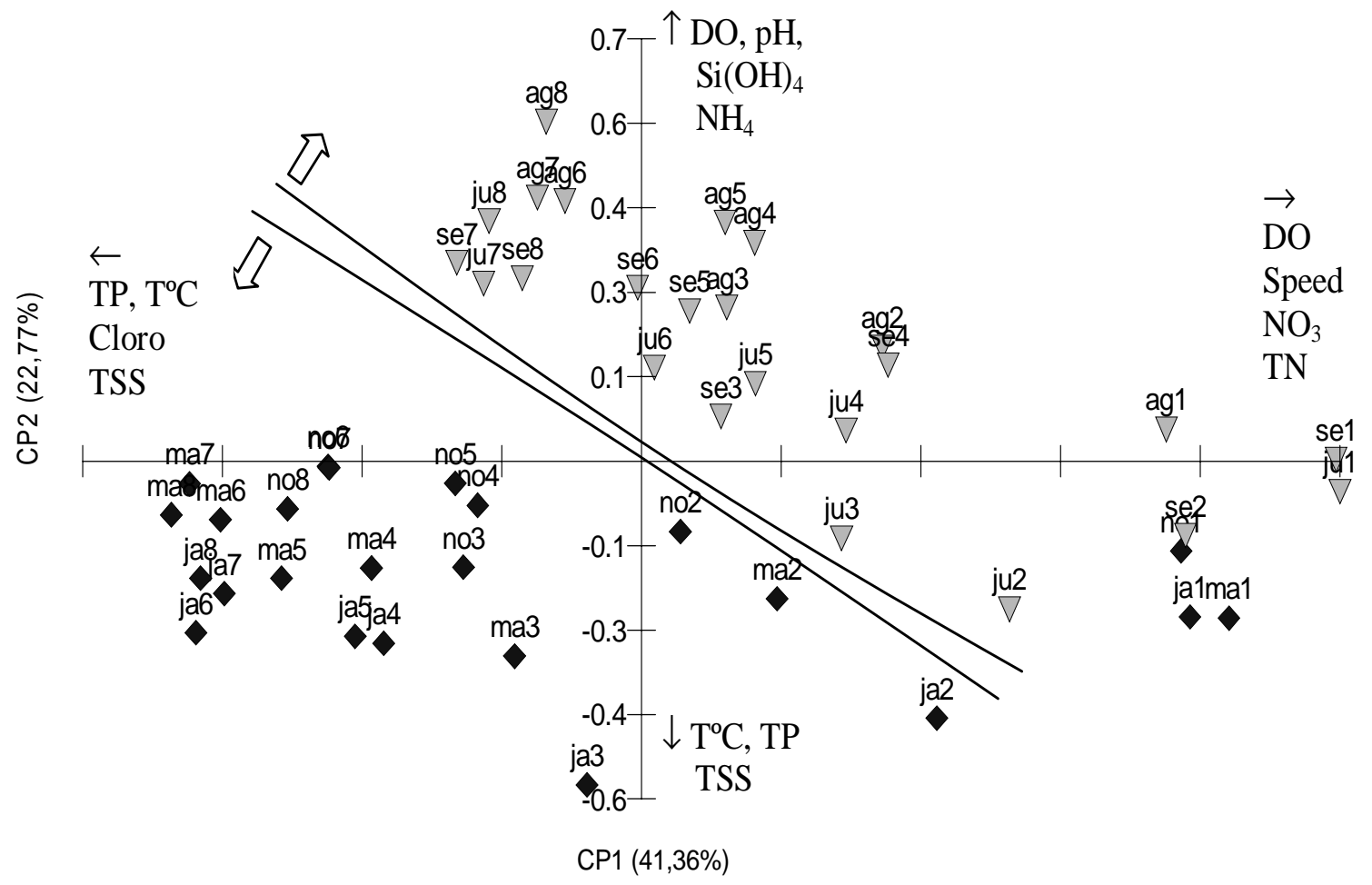

Figure 6 - Sampling spatiotemporal order by Principal Component Analysis. Eigenvalues: axis $1=7,031$ $(41,36 \%)$; Axis $2=3,871(22,77 \%)$. The higher-associated variables are indicated on the axes. Symbols: $\diamond$ Rainy season; $\nabla$ Dry season.

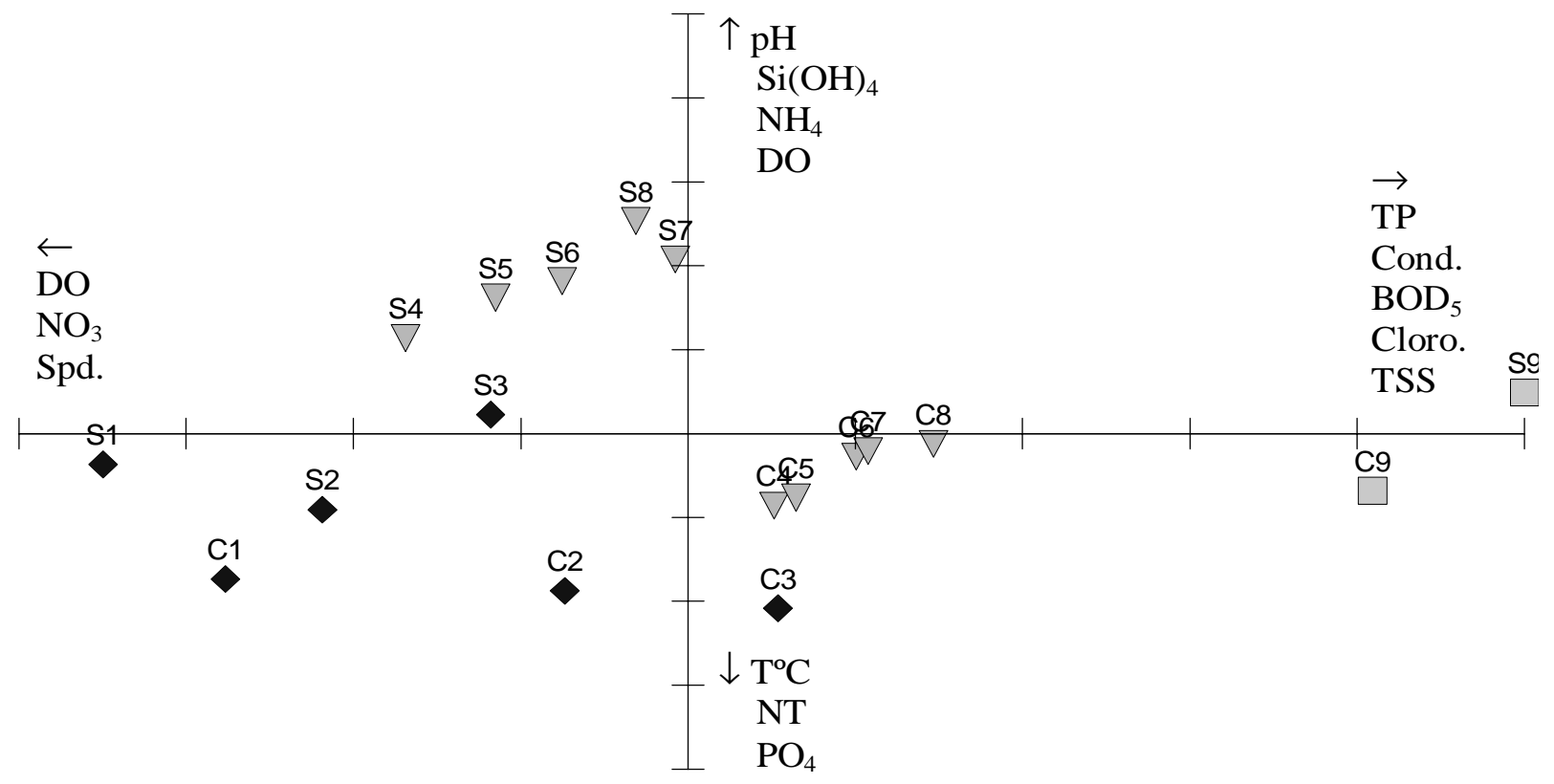

Figure 7 - Spatial ordering of sampling points in Dry season (S) and Rainy season (C), by Principal Component analysis. Eigenvalues: Axis $1=7,190$ (47,93\%); Axis $2=2,928$ (19,52\%). The higher-associated variables are indicated on the axes and the different symbols indicates the spatial grouping:

$\checkmark$ Springs; $\nabla$ Medium course; $\mathbf{W}$ Wetlands. 
The PCA was repeated using a simplified matrix (Fig. 7), in order to the better visualization of data and the exact definition of the river sections with homogeneous behavior. Thus, the variables were related to the 9 collection points (including point 9) in two sampling times (dry and rainy) in a total of 18 cases. Each point plotted represented the average of samples obtained from each season, identified by the initial letters of the season plus the sampling point number (e.g.: D4 = Dry season, point 4). The following patterns were observed: points R1, R2 and R3 formed a defined gradient. Another gradient could be observed on the points R4, R5, R6, R7 and R8, being the point $\mathrm{R} 9$ isolated. The same pattern for the dry season averages (D1 to D9). These results allowed to establish that:

1) the spatial gradient of the sampling points could be associated with the principal component 1 (axis1). The variables with higher associated eigenvalues were: dissolved oxygen, flow velocity, nitrate and total nitrogen (positively); total phosphorus, depth, temperature, chlorophylla and TSS (negatively);

2) the temporal gradient can be observed on the transverse direction to the axes, between the top right quadrant (dry season) and the bottom left (rainy season). The associated variables with this gradient were: $\mathrm{pH}$, dissolved oxygen, silicate and ammonium (positively); temperature, total phosphorus and TSS (negatively). These were the variables which presented the highest differences among the dry and rainy season (fig 3 to 5).

As postulated by ecological theories for lotic ecosystems, three patches are described:

1) Springs (points 1, 2 and 3). Relief (high declivity) and vegetation (preserved Atlantic Forest) determined a river section which proceeds exactly as foreseen by the River Continuum Concept (Vannote et al, 1980), applied to rivers of first to third order in forested watersheds. The main characteristics were: high oxigenation and transport of bigger particles due to flow velocity; low concentration of TSS and nutrients (except Nitrogen- $\mathrm{NO}_{3}$ ).

2) Medium course (points 4 to 8). At this section the slope is not too steep, and the variables were under influence of the Piraquara Dam. The characteristics were maintained during the whole course, and the gradients were smaller than the upstream section. However, this patch was under strong influence of seasonality, being more evident the differences between dry and rainy seasons. The variables TSS, Silicate, Conductivity and $\mathrm{pH}$ presented a continuous growing pattern.

3) Wetlands (point 9): These environment was very similar to lentic ecossystems and the main characteristics were the high contents of organic matter and low oxigenation.

Delimiting these patches, graphs and statistics allowed the identification of two main factors of serial discontinuity: a) the Piraquara Dam (between the points 3 and 4), with strong influence on the variables Silicate, TSS, Phosphate, Nitrite, Amonnium and Chlorophyll-a; and b) the wetlands occurrence (point 9), which modify most of the measured patterns. The transition of dendritic to meandric drainage pattern, motivated by the sedimentary basin (starting at point 6) did not produced variations.

The environmental variables adopted in this study did not prioritize the evaluation of sanitary conditions of the waterbody, but the general structure of the ecossystem. However, results suggest that the anthropogenic influence was not so strong than verified in other rivers of the region. Peaks of nutrients or conductivity, as well as evidences of domestic sewage were not found. At point 9, high values of nutrients, chlorophyll- $a$, $\mathrm{DBO}_{5}$ and low oxigen concentration characterize this section as the most fragile of the system, which was under strong anthropogenic influence over the last years, mainly by the irregular land occupation. The watershed zoning could be taken as an important basis for a wide biological monitoring program of the Upper Iguaçu River Basin, and the comparison among similar patches in different rivers will be quite useful for the identification of environmental disturbances.

\section{ACKNOWLEDGEMENTS}

We are grateful to the CEM/UFPR laboratory of Marine Biogeochemistry and to the biologists Nilva Brandini and Paulo R. Pagliosa Alves. Support: MEC/CAPES (Msc. study grant).

\section{RESUMO}

A bacia hidrográfica do rio Piraquara (Bacia do Alto Rio Iguaçu - PR) foi estudada como sistema 
ecológico ao longo de um ciclo sazonal completo, abrangendo os períodos seco e chuvoso. Análises de 16 variáveis físicas e químicas da água (oxigênio dissolvido, $\mathrm{pH}$, condutividade, $\mathrm{DBO}_{5}$, temperatura, nitrogênio total, fósforo total, ortofosfato, nitrito, nitrato, amônio, silicato, sólidos totais em suspensão, clorofila- $a$, profundidade e velocidade da corrente) demonstraram correlações entre a composição da água e as características fisiográficas da bacia. Os gradiente espaciais e as diferenças sazonais foram evidenciadas pela Análise de Componentes Principais, e a bacia foi dividida em trechos de comportamento homogêneo, sendo identificadas descontinuidades seriais: Trecho 1, com forte influência da Serra do Mar; Trecho 2, curso médio do rio, sob influência da Represa do Piraquara e Trecho 3, sob influência das várzeas. $\mathrm{O}$ trabalho Pretende subsidiar ações de pesquisa, planejamento e biomonitoramento para este manancial público.

\section{REFERENCES}

Asensio, L. J. (1988), Técnicas de análisis de datos multidimensionales. Ed. Espanha, Madrid.

Baptista, D. F.; Buss, D. F.; Dorvillé, L F. M. and Nessimian, J. L. (1998), O conceito de Continuidade de Rios é válido para rios de mata atlântica no sudeste de Brasil? In: Nessimian, J. L. and Carvalho, A. L. (eds.), Ecologia de Insetos Aquáticos. Série Oecologia Brasiliensis, 5. PPGE,UFRJ. Rio de Janeiro, Brasil. pp. 209-222.

Bretschko, G. (1995), River-land ecotones: scales and patterns. Hydrobiologia, 303, 83-91.

Branco, L. H. Z and Necchi Jr., O. (1997), Variação longitudinal de parâmetros físicos e químicos em três rios pertencentes a diferentes bacias de drenagem na região noroeste do Estado de São Paulo. Acta Limnológica Brasiliensia, 9, 165-177.

Camargo, A. F. M.; Ferreira, R. A. R.; Schiavetti, A. and Bini, L. M. (1996), Influence of physiography and human activity on limnological characteristics of lotic ecossystems of the south coast of São Paulo, Brazil. Acta Limnológica Brasiliensia, 8, 241-243.

Carvalho, A. R. (1996), Avaliação da qualidade da água e da interação entre o ecossistema aquático e o ecossistema terrestre em dois afluentes do Rio Jacaré-Guaçú, na APA de Corumbataí (Itirapina$S P)$. Dissertação de Mestrado. Escola de Engenharia de São Carlos, USP. 334 pp.

Garcia Agudo, E. (Coord.) (1987), Guia de coleta e preservação de amostras de água. São Paulo : CETESB.
COMEC - Coordenação da Região Metro-politana de Curitiba (1990), Mapa da Região Metropolitana de Curitiba. Curitiba : Governo do Estado do Paraná. 87 x $100 \mathrm{~cm}$, esc. 1:150.000.

Klein, R. M. and Hatschbach, G. F. (1962), Fitofisionomia e notas sobre a vegetação para acompanhar a planta fitogeográfica do município de Curitiba e arredores (Paraná) Boletim da Universidade do Paraná, Instituto de Geologia. Geografia Física, 4, 29.

Koroleff, F. (1976), Determinations of nutrients. In: Grasshof, K. (Ed.). Methods of Seawater Analysis. Verlag: Chemie. Weinhein. pp. 117-181.

Maack, R. (1981) Geografia Física do Estado do Paraná. 2. ed. Rio de Janeiro : J. Olympio.

Maltchik, L.; Molla, S.; Casado, C. and Montes, C. (1994), Measurement of nutrient spiralling in a Mediterranean stream: Comparison of two extreme hydrological periods. Arch. Hydrobiol., 130 : (2), 215-227.

Minshall, G. W.; Cummins, K. W.; Petersen, R. C.; Cushing, C. E.; Bruns, D. A.; Sedell, J. R. and Vannote, R. L. (1985), Developments in stream ecossystem theory. Can. J. Fish. Aquat. Sci., 42, 1045-1052.

Mulholland, P. J. (1992), Regulation of nutrient concentration in a temperate forest stream: Roles of upland, riparian and instream processes. Limnol. Oceanogr., 37 : (7), 1512-1526.

Newbold, J. D., Mulholland, P. J., Elwood, J. W. and O’Neill, R. V. (1982), Organic carbon spiralling in stream ecosystems. Oikos, 38, 266-272.

Prefeitura Municipal de Piraquara (1999), Plano Diretor do Município de Piraquara - PR. Secretaria Municipal de Agricultura e Meio Ambiente.

Pringle, C. M.; Naiman, R. J.; Bretschko, G.; Karr, J.; Oswood, M.; Webster, J.; Welcomme, R. and Winterbourn, M. J. (1988), Patch dynamics in lotic systems: the stream as a mosaic. J. N. Am. Benthol. Soc., 7, 503-524.

Reynolds, C. S. (1984), The ecology of freshwater phytoplankton. Cambridge : Cambridge University Press. 384 pp.

Rios, L. and Calijuri, M. C. (1995), A bacia hidrográfica do Ribeirão do Feijão: uma proposta para ordenação das sub-bacias através de variáveis limnológicas. Acta Limnologica Brasiliensia, 7, 151-161.

Rizzi, N. E. and Guiera, F. M. (1996), Análise de tipologias de ocupação da bacia hidrográfica do rio Iraí. Curitiba, UFPR. Agrárias, 15 : (2), 33-49.

Sabater, F., Armengol, J. and Sabater, S. (1989), Measuring discontinuites in the Ter river. Regulated Rivers: Res. Manag., 3, 133-142.

Strickland, J. H. D. and Parsons, T. R. (1972), A Pratical Handbook of Seawater Analysis. $2^{\text {nd }}$ ed. Bull. Fish. Res. BD Canada. 319 pp. 
Townsend, C.; Arbuckle, C. J.; Crowl, T. A. and Scarsbrook, M. R. (1997), The relationship between land use and physicochemistry, food resources and macroinvertebrate communities in tributaries of the Taieri River, New Zealand: a hierarchically scale aproach. Freshwater Biology, 37, 177-191.

Vannote, R. C.; Minshall, G. W.; Cummins, K.; Sedell, J. R. and Cushing, C. E. (1980), The river continuum concept. Can. J. Fish. Aquat. Sci., 37, 130-137.

Veloso, H. P.; Rangel Filho, A. L. R. and Lima, J. C. A. (1991), Classificação da vegetação brasileira adaptada a um sistema universal. Rio de Janeiro : IBGE, Departamento de Recursos Naturais e Estudos Ambientais. 123 pp.

Vicentini, A.; Tramujas, A. P. and Bonatto, F. (1991), Proposta de Plano de Manejo do Parque Estadual dos Mananciais da Serra. Monografia, Universidade Federal do Paraná, Curitiba, Paraná.

Ward, J. V. (1994), The structure and dynamics of lotic ecossystems. In: Elsevier Science, B. V. Limnology Now: A Paradigm for Planetary Problems.

Ziller, S. (1993), As formações vegetais da área de influência do futuro reservatório do Iraí Piraquara/Quatro Barras - PR. Curitiba : GTZ/PIAB.

Received: May 11, 2001; Revised: September 10, 2001; Accepted: May 15, 2002. 